\title{
Improvement of feed intake, digestibility, plasma metabolites, and lactation performance of dairy cows fed mixed silage of sugar beet pulp and rice straw inoculated with lactic acid bacteria
}

\author{
Y. Wang, ${ }^{1,2} \odot$ K. Xia, ${ }^{3}$ X. N. Wang, ${ }^{4}$ X. Lin, ${ }^{5}$ J. Liu, ${ }^{1}$ Y. J. Li, ${ }^{2}$ X. L. Liu, ${ }^{1 *}$ W. J. Zhao, ${ }^{6}$ Y. G. Zhang, ${ }^{2 *}{ }^{2}$ \\ and J. H. Guo ${ }^{1}$ \\ ${ }^{1}$ College of Food and Biological Engineering, Qiqihar University, Qiqihar, 161006, China \\ ${ }^{2}$ Animal Science and Technology Institute, Northeast Agriculture University, Harbin, 150030, China \\ ${ }^{3}$ China Oil and Foodstuffs Corporation, Harbin, 150000, China \\ ${ }^{4}$ Agricultural Experiment Base, Changchun, 130015, China \\ ${ }^{5}$ AB Agri Ltd., 200050, Shanghai, China \\ ${ }^{6}$ Harbin Wondersun Pasture, Heilongjiang Academy of Agricultural Sciences, Harbin, 150030, China
}

\begin{abstract}
A study was conducted to investigate the inclusion effects of sugar beet pulp and rice straw mixture silage with inoculation (BRMS), in place of whole-plant corn silage (CS), on the dry matter intake, total-tract nutrient digestibility, plasma metabolites, rumen fermentation, and lactation performance in high-production dairy cows. Sixteen multiparous Holstein cows (body weight, $622 \pm 35 \mathrm{~kg}$; days in milk, $90 \pm 11 \mathrm{~d}$; mean \pm standard deviation) were used in our experiments; the experiments were based on a repeated $4 \times 4$ Latin square design for $21 \mathrm{~d}$, and each experimental period consisted of $14 \mathrm{~d}$ of adaptation, followed by $7 \mathrm{~d}$ of data collection. The 4 dietary treatments used were (dry matter basis): (1) 0\% BRMS and 28.6\% CS (0BRMS); (2) $4.3 \%$ BRMS and $24.3 \%$ CS (15BRMS); (3) $8.60 \%$ BRMS and 20.0\% CS (30BRMS); and (4) $12.9 \%$ BRMS and $15.7 \%$ CS (45BRMS). The increasing inclusion of dietary BRMS was observed to linearly increase the total volatile fatty acids and the propionate concentration. The dry matter intake and digestibility values of neutral detergent fiber and acid detergent fiber increased linearly as the percentage of BRMS increased up to $45 \%$. Milk yield linearly increased with the increase in the content of BRMS $(39.0,39.8,40.9$, and $40.3 \mathrm{~kg} / \mathrm{d}$ for 0BRMS, 15BRMS, 30BRMS, and 45BRMS, respectively). The increasing inclusion of dietary BRMS induced a decrease in the ammonia nitrogen and milk urea nitrogen concentration, leading to a linear increase in milk protein production $(1.15,1.26,1.35$, and 1.27 $\mathrm{kg} / \mathrm{d}$ for 0BRMS, 15BRMS, 30BRMS, and 45BRMS,
\end{abstract}

Received March 28, 2021.

Accepted August 19, 2021.

*Corresponding authors: liuxiaolan001@126.com and zhangyonggen@sina.com respectively). In conclusion, the diets with the replacement of CS with BRMS up to $45 \%$ were beneficial to the production performance of high-production dairy cows, indicating that this method may be an appropriate use of sugar beet pulp and rice straw.

Key words: sugar beet pulp, mixture silage, inoculation, milk yield, milk protein

\section{INTRODUCTION}

High quality forage is critical to maintain rumen function, milk yield, and the health of high-producing dairy cows; dietary inclusion of forages with highly digestible NDF [whole-plant corn silage (CS) and alfalfa hay] have the potential to promote feed intake and increase milk yield (Wang et al., 2014; Ferraretto et al., 2015). However, both forages require considerable area of land and water and are difficult to achieve in unfavorable environments, which are encountered in several regions. Additionally, the excessive usage of dietary CS with a high starch content not only causes a risk of rumen acidosis (Kmicikewycz and Heinrichs, 2015), but also creates competition for human-edible feed (Vojvodić et al., 2016).

To compensate for the insufficient amount of high quality forage, feeding soybean husk, sugar beet pulp (SBP), apple pomace, and citrus pulp are viable options to improve the sustainability of dairy production systems by reducing the risk of rumen acidosis and decreasing the dietary proportion of human-edible products (Vojvodić et al., 2016; Zhao et al., 2017), and minimize the use of agricultural land and water for feed production (NRC, 2001). The inclusion of dietary byproducts with highly digestible NDF can replace CS with high digestible starch (Naderi et al., 2016; Heydari et al., 2021), and Miron et al. (2010) pointed out the necessity of increasing the converting efficiency from 
feed nutrients to animal products in high-production dairy cows.

Sugar beet pulp, which is a byproduct of sugar beet processing, is a common ingredient in the diet of dairy cows, and has a high NDF (Naderi et al., 2016) and pectic content (NRC, 2001). Fresh SBP has a high annual output (more than 3 million tons) in Heilongjiang province; therefore, it is an inexpensive fiber source that can be of interest to local farmers. Additionally, the SBP has high degradable NDF, pectic, and hemicellulose (galactan and arabinan) contents, and Ferraretto et al. (2015) reported that the DMI and milk of dairy cows fed CS with high NDF digestibility were higher than those fed CS with high starch digestibility, which indicated that the energy supply in the form of NDF is more efficient than that supplied in the form of starch. Miron et al. (2010) and Vojvodić et al. (2016) demonstrated that the dietary inclusion of nonforage fiber sources with high degradable fiber improved intake, health, and productivity. Several studies have shown that the inclusion of dietary SBP as nonforage fiber sources have positive effects on the production performance of dairy cows; Naderi et al. (2016) demonstrated that the use of SBP decreased the rumen ammonia nitrogen $\left(\mathrm{NH}_{3}-\mathrm{N}\right)$ concentration, corresponding to an increase in the milk yield and protein percentage, and Kahyani et al. (2019a) reported that the feed intake and milk protein yield of dairy cows tended to increase with the inclusion of SBP in the diet, which may be related to particle size, palatability, nutrient digestibility, and nitrogen utilization efficiency.

Fresh SBP is not easily ensiled owing to its high moisture content, and it is usually processed via drying. Drying is an energy- and cost-intensive procedure due to heat loss, and it causes air pollution-related problems; therefore, ensiling is considered an effective method to maintain the original nutritional value and extend the storage time of products. The inclusion of rice straw in the silage can not only reduce the moisture content to ensure the success of silage, but also can make use of large resources of rice straw (0.23 billion/ yr in China), effectively reducing environmental pollution induced by burning and discarding. Ensiling SBP and rice straw theoretically compensates for the insufficiency of physically effective NDF (peNDF) because rice straw is rich in lignocellulose and increases the fermentable substrate content, and because SBP has a high soluble fiber content.

Lactic acid bacteria (LAB) have been used as an additive to enhance the fermentation quality and the digestibility of straw silage (Guo et al., 2020), and ensiling high moisture amaranth and rice straw with inoculation (LAB) enhances the silage fermentation quality ( $\mathrm{Mu}$ et al., 2020), and the silage with inoculation (LAB) leads to a rapid reduction of the $\mathrm{pH}$ and acetic acid content (Oliveira et al., 2017).

It was hypothesized that the replacement of CS with sugar beet pulp and rice straw mixture silage (BRMS) would increase feed intake and milk yield of dairy cows. In this study, we developed a novel silage and investigated the inclusion effect of increasing the dietary concentration of BRMS at the expense of CS on the feed intake, total-tract nutrient digestibility, rumen fermentation, plasma metabolites, and lactation performance. The objective was to develop a high-quality forage for high-production dairy cows, which decreases the cost of feed and reduces environmental pollution.

\section{MATERIALS AND METHODS}

\section{Animals, Diets, and Experimental Design}

All experiments were conducted according to the principles and guidelines approved by the Animal Care and Use Committee of the Northeast Agriculture University. Sixteen multiparous Holstein cows (BW, $622 \pm$ $35 \mathrm{~kg}$; DIM, $90 \pm 11 \mathrm{~d}$; parity $2 \pm 1.2$; mean $\pm \mathrm{SD}$ ) were used in these experiments; the experiments were based on a repeated $4 \times 4$ Latin square design of $21 \mathrm{~d}(14 \mathrm{~d}$ of adaptation and $7 \mathrm{~d}$ of data collection). The dietary ingredients and chemical compositions are presented in Table 1, and Diamond V XP [the content of dried soy wine yeast culture (IFN7-05-520), 100\%; Diamond V Mills] and MetaSmart $\left[\mathrm{CH}_{3} \mathrm{~S}-\left(\mathrm{CH}_{2}\right)_{2}-\mathrm{CH}(\mathrm{OH})-\mathrm{COO}-\right.$ $\mathrm{CH}-\left(\mathrm{CH}_{3}\right)_{2}$ and CAS-Nr (7631-86-9): $10 \mathrm{SiO}_{2}\left(\mathrm{H}_{2} \mathrm{O}\right)$, less than 57\%; Adisseo] were used in the diet. The diet was formulated to meet the requirements of the dairy cows regarding protein, energy, minerals, and vitamins based on the Cornell-Penn-Miner model, and the treatment diets contained similar ingredients and forages, but different portions of CS and BRMS (replacing 0\%, $15 \%, 30 \%$, and $45 \%$ CS with BRMS, respectively, DM basis), and the oat hay needed to be chopped with a fodder chopper before the diet was sent to the TMR machine. Cows were housed in individual stalls, and clean wood shavings and sand were used for bedding and were refreshed daily. Cows were fed the TMR twice daily with ad libitum access to feed at 0600 and 1700 $\mathrm{h}$; the animals were allowed a $5 \%$ feed refusal, and the refusal was removed and weighed every day. The cows had free access to drinking water.

\section{Sample Collection, Measurements, and Analyses}

The CS (Wanghe No. 8) was provided from Jiusan Farm in Heilongjiang and was ensiled for $60 \mathrm{~d}$ in a 
silage pit; the harvest time of the CS lasted from September 9 to September 10, 2020. The CS samples were collected from multiple (8) spots of the received material and in triplicate from each spot. The SBP was obtained from Nanhua Sugar Trading Co. Ltd. Jiusan Farm in Heilongjiang, and the samples were collected from multiple spots ( 5 samples), and in triplicate from each spot. The rice straw was provided by Jiusan Farm and was chopped to approximately 2 to $3 \mathrm{~cm}$ in length using a fodder chopper. The mixture (BRM) was composited by the SBP sample and rice straw at a ratio of 9:1 (fresh material) manually, and it was sprayed with inoculants $\left(5 \times 10^{9} \mathrm{LAB} / \mathrm{g}\right)$ of fresh forage at 1 $\times 10^{11} \mathrm{cfu} / \mathrm{t}$ according to the recommended dose. Ten kilograms of each subsample was sampled and packed into laboratory-scale silos with ventilation $(10 \mathrm{~kg}, 46$ $\mathrm{cm} \times 65 \mathrm{~cm} \times 0.2 \mathrm{~mm})$; then the bags were sealed with a vacuum sealer (BH 950; Matsushita) and ensiled for $60 \mathrm{~d}$ (BRMS). The LAB inoculant (Lactobacillus delbrueckii ssp. bulgaricus ATCC BAA-365: Lactobacillus acidophilus ACCC10637, 1:1) was provided by Xinlaiwang Biotechnology Co. Ltd. The BRM and BRMS were sampled for chemical analysis.

The samples, including BRM, BRMS, CS, and TMR, were dried at $60^{\circ} \mathrm{C}$ in a forced-air oven for $48 \mathrm{~h}$ and ground using a Wiley mill through a 1-mm screen

Table 1. Ingredients and chemical composition [mean (SD)] of the experimental diets

\begin{tabular}{|c|c|c|c|c|}
\hline \multirow[b]{2}{*}{ Item } & \multicolumn{4}{|c|}{$\operatorname{Diet}^{1}$} \\
\hline & Control & 15BRMS & 30BRMS & 45BRMS \\
\hline \multicolumn{5}{|l|}{ Ingredient $(\%$ of $\mathrm{DM})$} \\
\hline BRMS & - & 4.30 & 8.57 & 12.9 \\
\hline Corn silage & 28.6 & 24.3 & 20.00 & 15.7 \\
\hline Corn & 22.5 & 22.5 & 22.5 & 22.6 \\
\hline Alfalfa hay & 11.3 & 11.3 & 11.3 & 11.3 \\
\hline Oat hay & 6.14 & 6.14 & 6.14 & 6.14 \\
\hline Soybean meal & 1.59 & 1.59 & 1.59 & 1.59 \\
\hline Rapeseed meal & 9.40 & 9.40 & 9.40 & 9.40 \\
\hline Wheat bran & 9.27 & 9.27 & 9.27 & 9.27 \\
\hline Cottonseed meal & 7.44 & 7.44 & 7.44 & 7.44 \\
\hline $2 \%$ Premix $^{2}$ & 1.00 & 1.00 & 1.00 & 1.00 \\
\hline Calcium carbonate & 0.79 & 0.79 & 0.79 & 0.79 \\
\hline Sodium bicarbonate & 0.84 & 0.84 & 0.84 & 0.84 \\
\hline Diamond V XP ${ }^{3}$ (yeast culture) & 0.38 & 0.38 & 0.38 & 0.38 \\
\hline Calcium phosphate dihydrate & 0.42 & 0.42 & 0.42 & 0.42 \\
\hline Salt $/ \mathrm{NaCl}$ & 0.21 & 0.21 & 0.21 & 0.21 \\
\hline MetaSmart $^{4}$ (rumen-protected Met) & 0.17 & 0.17 & 0.17 & 0.17 \\
\hline \multicolumn{5}{|l|}{ Chemical composition ( $\%$ of DM) } \\
\hline $\mathrm{CP}$ & $17.0(0.37)$ & $17.2(0.22)$ & $17.4(0.23)$ & $17.6(0.20)$ \\
\hline $\mathrm{SCP}^{5}(\%$ of $\mathrm{CP})$ & $31.7(0.35)$ & $31.6(0.44)$ & $31.7(0.36)$ & $30.9(0.35)$ \\
\hline NDF & $31.7(0.44)$ & $32.3(0.57)$ & $32.8(0.43)$ & $33.4(0.12)$ \\
\hline $\operatorname{peNDF}^{6}(\%$ of DM) & $23.1(0.56)$ & $22.4(0.78)$ & $21.7(0.55)$ & $21.0(0.64)$ \\
\hline $\mathrm{ADF}$ & $19.4(0.18)$ & $19.5(0.41)$ & $19.6(0.34)$ & $19.7(0.34)$ \\
\hline ADL & $3.81(0.14)$ & $3.91(0.12)$ & $4.0(0.14)$ & $4.10(0.19)$ \\
\hline $\mathrm{NFC}^{7}$ & $42.0(0.36)$ & $41.1(0.36)$ & $40.4(0.39)$ & $39.6(0.20)$ \\
\hline Ether extract & $3.59(0.18)$ & $3.56(0.28)$ & $3.5(0.13)$ & $3.48(0.22)$ \\
\hline Starch & $29.3(0.35)$ & $28.1(0.44)$ & $27.0(0.32)$ & $25.8(0.21)$ \\
\hline Soluble fiber & $5.48(0.44)$ & $6.12(0.30)$ & $6.75(0.23)$ & $7.39(0.15)$ \\
\hline
\end{tabular}

${ }^{1}$ 15BRMS, 30BRMS, and 45BRMS indicate the 15\%,30\%, and 45\% replacement of corn silage with sugar beet pulp and rice straw mixture silage (BRMS), respectively.

${ }^{2}$ Premix was composed of vitamin $\mathrm{A}$, vitamin $\mathrm{D}_{3}$, vitamin $\mathrm{E}$, manganese sulfate, zinc sulfate, magnesium oxide, limestone, and sodium chloride, and the chemical composition of the premix contained (DM basis) $99.17 \%$ ash, $14.25 \% \mathrm{Ca}, 5.40 \% \mathrm{P}, 4.93 \% \mathrm{Mg}, 0.05 \% \mathrm{~K}, 10.64 \% \mathrm{Na}, 2.95 \% \mathrm{Cl}, 0.37 \% \mathrm{~S}, 12 \mathrm{mg} / \mathrm{kg} \mathrm{Co}, 500 \mathrm{mg} / \mathrm{kg} \mathrm{Cu}, 4,858$ $\mathrm{mg} / \mathrm{kg} \mathrm{Fe}, 25 \mathrm{mg} / \mathrm{kg} \mathrm{I}, 800 \mathrm{mg} / \mathrm{kg} \mathrm{Mn}, 10 \mathrm{mg} / \mathrm{kg} \mathrm{Se}, 1,800 \mathrm{mg} / \mathrm{kg} \mathrm{Zn}, 180,000 \mathrm{IU} / \mathrm{kg}$ vitamin A, 55,000 IU/ $\mathrm{kg}$ vitamin $\mathrm{D}$, and $1,500 \mathrm{IU} / \mathrm{kg}$ vitamin $\mathrm{E}$ (Diamond V Mills).

${ }^{3}$ Diamond V XP, the content of dried soy wine yeast culture (IFN7-05-520) is 100\%, and guaranteed values are $\mathrm{CP} \geq 15 \%$, ether extract $\geq 0.5 \%, \mathrm{CF} \leq 32 \%$, ash $\leq 12 \%$, water $\leq 10 \%$, mannan $\geq 2 \%$ (Diamond V Mills).

${ }^{4}$ MetaSmart is composed of $\mathrm{CH}_{3} \mathrm{~S}-\left(\mathrm{CH}_{2}\right)_{2}-\mathrm{CH}(\mathrm{OH})-\mathrm{COO}-\mathrm{CH}-\left(\mathrm{CH}_{3}\right)_{2}$ and CAS-Nr [7631-86-9]: $10 \mathrm{SiO}_{2}\left(\mathrm{H}_{2} \mathrm{O}\right)$, and the guaranteed value of 2-hydroxy-4-methylthiobutyrate isopropyl is not lower than $57 \%$ (Adisseo).

${ }^{5} \mathrm{SCP}=$ soluble crude protein.

${ }^{6}$ peNDF $=$ physically effective NDF determined as the NDF content of TMR multiplied by physically effective fiber $>1.18$.

${ }^{7} \mathrm{NFC}=100-\% \mathrm{NDF}-\%(\mathrm{CP}-$ neutral detergent insoluble crude protein $)-\%$ ether extract $-\%$ ash. 
(FZ102, Taisite Instrument Co. Ltd.). The BRM samples were collected by multipoint sampling, and the nutrition compositions of BRM were analyzed. The BRMS, CS, and TMR samples were collected weekly, and the nutrition compositions were analyzed. The DM, ether extract, and $\mathrm{CP}$ contents were analyzed according to the procedures 934.01, 920.35, and 976.05, respectively, of AOAC (1990). The NDF and ADF contents were sequentially analyzed using the Ankom A200 fiber analyzer (Ankom Technology), and the NDF content was determined according to the method by Van Soest et al. (1991) using heat-stable $\alpha$-amylase and sodium sulfite, and the ADF content was determined according to the 954.01 procedure of AOAC (1990). The starch content was analyzed using the anthrone shade selection method (Guo et al., 2007). The neutral detergent insoluble crude protein (NDICP) and acid detergent insoluble $\mathrm{CP}$ contents were measured by analyzing the $\mathrm{CP}$ content in NDF and ADF, respectively. The ADL content was determined using the methods of Licitra et al. (1996). The soluble CP content was measured using the Folin-phenol method (Licitra et al., 1996), and the NPN content was calculated as the difference between the soluble protein and the protein precipitated in trichloroacetic acid (Licitra et al., 1996). The watersoluble carbohydrate (WSC) content was determined using the sulfuric acid-anthrone method (Sun et al., 2016). The physically effective fiber (pef) and peNDF contents were determined using the method by Yang and Beauchemin (2006). Particle size was measured in triplicate using the Penn State Particle Separator equipped with 3 sieves and a bottom pan. The formulas used for the pef and peNDF were pef $f_{1.18}=\mathrm{DM} 19 \mathrm{~mm}$ (the proportion of particles retained) $+\mathrm{DM} 8 \mathrm{~mm}$ (the proportion of particles retained) + DM $1.18 \mathrm{~mm}$ (the proportion of particles retained)/100 and peNDF $=$ pef $\times$ NDF\%, respectively.

The quality of the silage was evaluated using the Vscore rating system (Gao et al., 2016). The $\mathrm{pH}$ value was determined using a pH meter (Sartorius, PB-10). The lactic acid concentration was determined using HPLC, and the concentrations of VFA were measured using a Shimadzu GC-2010 gas chromatograph (Jiang et al., 2020; Agilent capillary column $(30.0 \mathrm{~m} \times 320$ $\mu \mathrm{m} \times 0.5 \mu \mathrm{m}$; Agilent Technologies Inc.). The loading conditions used were that the temperature of the inlet and the detector was $220^{\circ} \mathrm{C}$; heating temperature of the column oven: the initial temperature was $120^{\circ} \mathrm{C}$, which was maintained for $3 \mathrm{~min}$, then was increased to $180^{\circ} \mathrm{C}$ at $10^{\circ} \mathrm{C} / \mathrm{min}$; the carrier gas used was high-purity nitrogen; the inlet pressure was maintained at $90 \mathrm{kPa}$; the flow rate of hydrogen used was $40 \mathrm{~mL} / \mathrm{min}$; the air flow rate was $400 \mathrm{~mL} / \mathrm{min}$; and the makeup flow rate was $45 \mathrm{~mL} / \mathrm{min}$. The ruminal $\mathrm{NH}_{3}-\mathrm{N}$ concentration was determined using the colorimetric phenol-hypochlorite method described by Broderick and Kang (1980). The concentration values of mycotoxins (aflatoxin $\mathrm{B}_{1}$, zearalenone, deoxynivalenol, and ochratoxin) in the CS and BRMS were determined by the Inspection and Quarantine Technology Center of Heilongjiang Entry-Exit Inspection and Quarantine Bureau, according to the GB/T 30955 (Standardization Administration, 2014), GB/T 28716 (Standardization Administration, 2012), GB/T 30956 (Standardization Administration, 2014), and GB/T 30957 (Standardization Administration, 2014) methods, respectively.

\section{Intake and Digestibility}

The TMR offered and refused was measured daily for each cow, and the nutrient compositions (DM, CP, and NDF) of TMR and the refusals were determined. The DMI value for each cow was calculated, and refusals from individual cows were used to calculate the nutrient (DM, CP, and NDF) intake. On the last $3 \mathrm{~d}$ of each experimental period, approximately $500 \mathrm{~g}$ of the fecal samples were collected from the rectum at 0600 and $1800 \mathrm{~h}$ and composited for each individual cow. The apparent total-tract digestibility values of nutrients were determined using acid-insoluble ash as an internal marker (Lee and Hristov, 2013).

\section{Rumen Sampling and Analyses}

On d 19, 20, and 21 of each period, ruminal fluid samples were collected using an oral stomach tube approximately $3 \mathrm{~h}$ after the morning feed delivery (Wang et al., 2014). We threw away the first 100 to $200 \mathrm{~mL}$ of fluid collected through the stomach tube to reduce the chance that stomach-tube rumen samples were contaminated with saliva before ruminal fluid samples were collected. Ruminal digesta samples were squeezed in a 4-layer cheesecloth to obtain a ruminal fluid sample $(250 \mathrm{~mL})$. The rumen fluid was centrifuged at $1,500 \times g$ for $15 \mathrm{~min}$, and the supernatant was collected and frozen for determination of the concentration of $\mathrm{NH}_{3}-\mathrm{N}$ and VFA. The methods used for the $\mathrm{NH}_{3}-\mathrm{N}$ and VFA assays were the same as the methods used for the analyses of fresh samples.

\section{Plasma Sampling and Analysis}

On d 18 of each period, blood samples $(10 \mathrm{~mL})$ were collected via the coccygeal vein with an anticoagulant at approximately $3 \mathrm{~h}$ after the morning feed. Blood samples were placed on ice immediately after collection and centrifuged at 3,000 $\times g$ for $15 \mathrm{~min}$, and the plasma was separated and frozen to $-20^{\circ} \mathrm{C}$ until analysis. Com- 
mercial kits (Nanjing Jiancheng Bioengineering Institute) were used to determine the plasma concentration values of glucose, triglyceride, total cholesterol, BHB , urea nitrogen (UN), and total protein (TP), according to the manufacturer's instructions.

\section{Milk Yield and Components}

The dairy cows were milked 3 times a day at 0700 , 1500 , and $2300 \mathrm{~h}$, and the milk yield was recorded at each milking. On d 15, 16, and 17 of each period, the milk samples $(50 \mathrm{~mL})$ were collected in the morning, afternoon, and evening, and mixed well at a ratio of $4: 3: 3$ (based on the production), then preserved with potassium dichromate and stored at $4^{\circ} \mathrm{C}$. The milk samples were sent to Nestlé DFI to determine the concentration of fat, milk, and lactose using an infrared milk composition analyzer (MilkoScan 605, Foss Electric). The concentration of MUN was determined using an enzymatic assay (Wilson et al., 1998). The 3.5\% FCM and ECM were calculated according to the guidelines from $\mathrm{NRC}(2001): \mathrm{FCM}=0.432 \times$ milk yield +16.23 $\times$ fat yield; $\mathrm{ECM}=$ milk production $\times(0.383 \times \%$ fat $+0.242 \times \%$ protein +0.7832$) / 3.1183$.

\section{Data Processing}

The data were analyzed using a Latin square design and the MIXED procedure of SAS (9.3.1, SAS Institute Inc.), and the differences among the treatments were assessed using LSMEANS with the PDIFF procedure in SAS. The following model was used for the analysis as a replicated $4 \times 4$ Latin square design: $\mathrm{Y}_{i j k m}=\mu$ $+\mathrm{S}_{i}+\mathrm{C}(\mathrm{S})_{i j}+\mathrm{P}_{k}+\mathrm{T}_{m}+\mathrm{E}_{i j k m}$, where $\mathrm{Y}_{i j k m}$ is the dependent variable, $\mu$ is the overall mean, $\mathrm{S}_{i}$ is the fixed effect of square $I, \mathrm{C}(\mathrm{S})_{i j}$ is the random effect of cow $j$ within square $I, \mathrm{P}_{k}$ is the fixed effect of period $k$, $\mathrm{T}_{m}$ is the fixed effect of treatment $m$, and $\mathrm{E}_{i j k m}$ is the residual error. Differences were considered statistically significant at $P \leq 0.05$, and highly significant values were defined as $P<0.01$, and trends were reported at $0.05<P \leq 0.10$. Orthogonal polynomial contrasts (linear, quadratic, and cubic) were used to examine the treatment effects on the response variables.

\section{RESULTS}

\section{Chemical Composition of the Nutritional Ingredients of BRMS}

The chemical composition of SBP and rice straw are presented in Table 2. The CP and NDF contents of fresh SBP were $14.8 \% \mathrm{DM}$ and $51 \% \mathrm{DM}$, respectively, and the NDF content of rice straw was $75 \%$ DM, which are all higher than those obtained previously. The DM content of the BRM at a ratio of 9 to 1 was $300 \mathrm{~g} / \mathrm{kg}$, and the WSC content was $41.1 \mathrm{~g} / \mathrm{kg}$.

The chemical composition (BRM, BRMS, and CS) and silage quality (BRMS and CS) are presented in Table 3 , and the contents of the different mycotoxins are presented in Table 4. The CP content of BRMS was higher than that of BRM, and increased by $5.78 \%$. The DM and WSC contents of BRMS were lower than those of BRM, and decreased by $5.67 \%$ and $17.07 \%$, respectively. The BRMS had a low starch content $(3.2 \%$ DM) compared with that of CS (30.6\% DM); therefore, the dietary starch content decreased by $1.2 \%, 2.3 \%$, and $3.5 \%$, respectively, with the increasing inclusion of BRMS, which rapidly reduced the risk of rumen acidosis caused by starch fermentation. The SBP had a higher NDICP content $(6.81 \% \mathrm{DM}$, an indicator of RUP) compared with that of CS, which indicated that it had a high efficiency of protein utilization. The CS and BRMS were above 80 , as evaluated using the Vscore system, and the levels of aflatoxin $\mathrm{B}_{1}$, zearalenone, deoxynivalenol, and ochratoxin A were all far below the prescribed limitation values, which indicated that the BRMS had high quality and safety.

\section{Intake and Total-Tract Digestibility of Nutrients}

The nutrient intake and total-tract digestibility of replacing CS with BRMS are listed in Table 5. The CP, $\mathrm{NDF}$, and ADF intake linearly increased with the in-

Table 2. Chemical composition and quality evaluation of sugar beet pulp and rice straw (\% of DM unless otherwise noted; mean $\pm \mathrm{SD}$ )

\begin{tabular}{lcr}
\hline Item $^{1}$ & Sugar beet pulp & Rice straw \\
\hline DM $(\%)$ & $23.0 \pm 0.26$ & $93.0 \pm 0.35$ \\
CP & $14.8 \pm 0.24$ & $5.4 \pm 0.22$ \\
Soluble protein & $6.37 \pm 0.30$ & $1.89 \pm 0.10$ \\
NPN & $5.92 \pm 0.32$ & $1.82 \pm 0.21$ \\
ADICP & $0.85 \pm 0.04$ & $0.33 \pm 0.10$ \\
NDICP & $6.81 \pm 0.23$ & $1.68 \pm 0.20$ \\
ADF & $23.0 \pm 0.33$ & $45.0 \pm 1.96$ \\
NDF & $51.1 \pm 0.95$ & $75.0 \pm 0.37$ \\
peNDF & $25.6 \pm 0.34$ & $75.0 \pm 0.37$ \\
ADL & $5.31 \pm 0.23$ & $10.5 \pm 0.25$ \\
Ash & $11.9 \pm 0.40$ & $10.5 \pm 0.27$ \\
NFC & $28.1 \pm 0.3$ & $7.17 \pm 0.18$ \\
Ether extract & $0.90 \pm 0.08$ & \\
Sugar & $5.06 \pm 0.19$ & $2.30 \pm 0.22$ \\
Starch & $2.81 \pm 0.22$ & $1.29 \pm 0.16$ \\
WSC & $4.99 \pm 0.03$ & $2.17 \pm 0.21$ \\
\hline
\end{tabular}

${ }^{1} \mathrm{ADICP}=$ acid detergent insoluble crude protein; $\mathrm{NDICP}=$ neutral detergent insoluble crude protein; peNDF $=\mathrm{NDF} \times$ pef (physically effective fiber) $>1.18$ (3 sieve) (Penn State Particle Separator); NFC $=100$ $-\% \mathrm{NDF}-\%(\mathrm{CP}-\mathrm{NDICP})-\%$ ether extract $-\%$ ash; WSC $=$ water-soluble carbohydrates. 
Table 3. Chemical composition and quality evaluation of sugar beet pulp and rice straw mixture (BRM), sugar beet pulp and rice straw mixture silage (BRMS), and corn silage [\% of DM unless otherwise noted; mean (SD)]

\begin{tabular}{lrrr}
\hline Item $^{1}$ & \multicolumn{1}{c}{ BRM } & \multicolumn{1}{c}{ BRMS } & Corn silage \\
\hline DM $(\%)$ & $30.0(0.38)$ & $28.7(0.11)$ & $28.5(0.51)$ \\
CP & $12.1(0.24)$ & $12.8(0.91)$ & $7.8(0.22)$ \\
Soluble CP & $5.6(0.11)$ & $5.7(0.16)$ & $4.6(0.32)$ \\
NPN & $5.2(0.22)$ & $5.3(0.16)$ & $4.6(0.35)$ \\
ADICP & $0.7(0.02)$ & $0.7(0.05)$ & $0.9(0.11)$ \\
NDICP & $5.3(0.07)$ & $5.3(0.12)$ & $1.2(0.15)$ \\
ADF & $29.8(0.23)$ & $28.9(0.24)$ & $27.5(0.44)$ \\
NDF & $58.5(0.41)$ & $57.7(0.20)$ & $45.3(0.56)$ \\
peNDF & $40.9(0.33)$ & $40.7(0.15)$ & $39.8(1.22)$ \\
ADL & $6.1(0.31)$ & $6.1(0.25)$ & $3.7(0.11)$ \\
Ash & $11.5(0.21)$ & $11.5(0.07)$ & $5.1(0.14)$ \\
NFC & $21.5(0.28)$ & $23.6(0.32)$ & $40.4(1.05)$ \\
Starch & $1.4(0.09)$ & $1.3(0.19)$ & $29.9(0.85)$ \\
WSC & $4.1(0.26)$ & $3.4(0.26)$ & $3.7(0.37)$ \\
Fermentation quality & & & $4.1(0.15)$ \\
pH & - & $3.9(0.25)$ & $3.8(0.18)$ \\
Lactic acid & - & $4.3(0.33)$ & $0.9(0.07)$ \\
Acetic acid & - & $1.8(0.09)$ & $0.1(0.01)$ \\
Propionic acid & - & $0.2(0.02)$ & $0.1(0.01)$ \\
Butyric acid & - & $3.15(0.15)$ & $5.56(0.22)$ \\
NH S $_{3}$ /total N & - & $>80$ & $>80$ \\
Score & - & & \\
\hline
\end{tabular}

${ }^{1}$ ADICP, acid detergent insoluble crude protein; NDICP, neutral detergent insoluble crude protein; peNDF $=$ NDF $\times$ pef (physically effective fiber) $>1.18$ (Penn State Particle Separator); NFC $=100-\%$ NDF $-\%(C P$ - NDICP) $-\%$ ether extract $-\%$ ash.

crease in BRMS to up to $45 \%(P=0.02, P<0.01$, and $P=0.02$, respectively), and they increased by $8.68 \%$, $10.78 \%$, and $6.73 \%$, respectively. The peNDF linearly tended to decrease with the increasing replacement with BRMS up to $45 \%(P=0.07)$. The DM digestibility linearly tended to increase as the BRMS increased to up to $45 \%(P=0.07)$, and it quadratically increased $(P=0.02)$, and it increased by $2.52 \%$. The CP digestibility linearly tended to increase as the dietary BRMS reached $45 \%(P=0.07)$. The NDF and ADF digestibility values linearly increased as the BRMS increased up to $45 \%$ ( $P<0.01$ and $P=0.02$, respectively), and increased to $54.5 \%$ and $46.6 \%$, respectively.

\section{Rumen Fermentation}

The effects of replacing CS with BRMS on rumen fermentation are presented in Table 6 . The total VFA

Table 4. Concentration of different mycotoxins $(\mu \mathrm{g} / \mathrm{kg})$ of sugar beet pulp and rice straw mixture silage (BRMS) and corn silage

\begin{tabular}{lccc}
\hline Item & BRMS & Corn silage & Range of calibration \\
\hline Aflatoxin $\mathrm{B}_{1}$ & $<0.2$ & $<0.2$ & $<20$ \\
Zearalenone & $<0.2$ & $<0.2$ & $<500$ \\
Deoxynivalenol & 98.2 & 165 & $<5,000$ \\
Ochratoxin A & $<0.2$ & $<0.2$ & $<100$ \\
\hline
\end{tabular}

concentration in the rumen linearly increased to 101 $\mathrm{mmol} / \mathrm{L}$ with the inclusion of dietary BRMS, increasing up to $45 \%(P=0.04)$, and the propionate acid concentration increased to $23.9 \mathrm{mmol} / \mathrm{L}$ as the substitution of BRMS increased up to $45 \%(P=0.02)$. The ruminal caproic concentration linearly tended to increase with the increasing replacement with BRMS up to $45 \%$ ( $P$ $=0.08$ ). The ruminal $\mathrm{NH}_{3}-\mathrm{N}$ concentration linearly decreased as the dietary BRMS reached $45 \%(P=0.01)$, and decreased by $4.1 \%$. The ratio of the concentrations of acetate and butyrate was not affected by increasing the content of dietary BRMS.

\section{Analysis of Plasma Metabolites}

The effects of replacing CS with BRMS on plasma metabolites are shown in Table 7. The plasma concentrations of glucose, triglyceride, and albumin/globulin were not affected by the $\operatorname{diet}(P>0.10)$. The plasma concentration of TP linearly increased $(P=0.01)$ as the BRMS increased to up to $45 \%$, and increased by $2.62 \%$. The plasma concentration of BHB linearly decreased with the increasing replacement with BRMS up to $45 \%(P=0.02)$, and plasma concentration of BHB decreased by $13.33 \%$. The plasma concentration of UN linearly decreased as the replacement of BRMS increased up to $45 \%(P=0.02)$, and plasma concentration of UN decreased by $5.49 \%$. 
Table 5. Intake and total-tract apparent digestibility of dairy cows fed diets with the inclusion of dietary sugar beet pulp and rice straw mixture silage (BRMS)

\begin{tabular}{|c|c|c|c|c|c|c|c|c|}
\hline \multirow[b]{2}{*}{ Item } & \multirow[b]{2}{*}{ Control } & \multicolumn{3}{|c|}{ Treatment $^{1}$} & \multirow[b]{2}{*}{ SEM } & \multicolumn{3}{|c|}{$P$-value ${ }^{2}$} \\
\hline & & 15BRMS & 30BRMS & 45BRMS & & $\mathrm{L}$ & $\mathrm{Q}$ & $\mathrm{C}$ \\
\hline \multicolumn{9}{|c|}{ Intake $(\mathrm{kg} / \mathrm{d})$} \\
\hline $\mathrm{CP}$ & 4.03 & 4.23 & 4.40 & 4.38 & 0.05 & 0.02 & 0.13 & 0.62 \\
\hline NDF & 7.51 & 7.94 & 8.30 & 8.32 & 0.10 & $<0.01$ & 0.14 & 0.67 \\
\hline peNDF $^{3}$ & 5.47 & 5.51 & 5.49 & 5.23 & 0.05 & 0.07 & 0.11 & 0.64 \\
\hline $\mathrm{ADF}$ & 4.60 & 4.80 & 4.96 & 4.91 & 0.05 & 0.01 & 0.13 & 0.62 \\
\hline $\mathrm{CP}$ & 63.5 & 66.0 & 69.5 & 68.0 & 0.45 & 0.07 & 0.42 & 0.57 \\
\hline $\mathrm{NDF}$ & 50.2 & 52.8 & 54.6 & 54.5 & 0.60 & $<0.01$ & 0.31 & 0.78 \\
\hline $\mathrm{ADF}$ & 42.5 & 44.6 & 46.6 & 46.6 & 0.55 & 0.02 & 0.36 & 0.60 \\
\hline
\end{tabular}

${ }^{1}$ Treatment: 15BRMS, 30BRMS, and 45BRMS indicate the 15\%,30\%, and 45\% replacement of CS with BRMS, respectively.

${ }^{2}$ Probabilities of linear (L), quadratic (Q), and cubic (C) effects.

${ }^{3}$ peNDF $=$ NDF $\times$ pef $($ physically effective fiber $)>1.18$ (3 sieve) $($ Penn State Particle Separator $)$.

\section{Milk Yield and Milk Components}

The DMI values and lactation performance of the dairy cows fed the diets with BRMS are presented in Table 8. The DMI values linearly increased with the replacement of CS with BRMS by up to $45 \%(P=$ 0.03). The enhancing inclusion of dietary BRMS linearly increased the milk yield $(P=0.048)$, and the values of ECM linearly increased with the replacement with BRMS by up to $45 \%(P<0.01)$. The milk fat percentage and production were not affected with the increasing inclusion of dietary BRMS $(P=0.14$ and $P=$ 0.91, respectively), and the milk lactose ratio and milk lactose production were not affected $(P=0.58$ and $P$ $=0.12$, respectively). The milk protein percentage linearly and quadratically increased with the replacement with BRMS by up to $45 \%(P=0.05$ and $P=0.04$, respectively), and the milk protein production linearly increased $(P=0.02)$. The MUN linearly decreased as the replacement of BRMS increased up to $45 \%(P<$ 0.01). The feed efficiencies (milk yield/DMI and FCM/
DMI) were not affected by the diets with an increased inclusion of dietary BRMS $(P=0.47$ and $P=0.61$, respectively). In general, the milk yield, milk protein percentage, and production increased as the dairy cows were fed the diets with increased replacement levels of BRMS for CS and this had no unfavorable effects on the health of the animals.

\section{DISCUSSION}

The CP content (14.8\% DM) of SBP was higher than that in previous reports (Naderi et al., 2016; Kahyani et al., 2019a), the NDF content (51.1\% DM) was greater than that in other reports (Kahyani et al., 2019a; Heydari et al., 2021), and the NDF content (75\% DM) of rice straw was greater than the result reported by $\mathrm{Mu}$ et al. (2020). The differences in nutritional composition may derive from different fertilization harvest seasons, sowing densities, or irrigation methods.

In the current study, the BRM had an appropriate DM content $(>250 \mathrm{~g} / \mathrm{kg}$ of fresh weight; McDonald

Table 6. Effect of replacing corn silage with sugar beet pulp and rice straw mixture silage (BRMS) on rumen fermentation of dairy cows

\begin{tabular}{|c|c|c|c|c|c|c|c|c|}
\hline \multirow[b]{2}{*}{ Item } & \multirow[b]{2}{*}{ Control } & \multicolumn{3}{|c|}{ Treatment $^{1}$} & \multirow[b]{2}{*}{ SEM } & \multicolumn{3}{|c|}{$P$-value ${ }^{2}$} \\
\hline & & 15BRMS & 30BRMS & 45BRMS & & $\mathrm{L}$ & $Q$ & $\mathrm{C}$ \\
\hline Acetate $(\mathrm{m} M)$ & 60.6 & 62.9 & 64.3 & 62.8 & 0.76 & 0.26 & 0.24 & 0.78 \\
\hline Propionate $(\mathrm{m} M)$ & 21.6 & 23.6 & 24.9 & 23.9 & 0.39 & 0.02 & 0.05 & 0.59 \\
\hline Butyrate $(\mathrm{m} M)$ & 7.23 & 6.98 & 7.38 & 6.88 & 0.15 & 0.66 & 0.70 & 0.30 \\
\hline Isovalerate $(\mathrm{m} M)$ & 1.37 & 1.38 & 1.37 & 1.41 & 0.01 & 0.22 & 0.44 & 0.42 \\
\hline Acetate:propionate & 2.81 & 2.69 & 2.59 & 2.63 & 0.06 & 0.25 & 0.49 & 0.83 \\
\hline Rumen $\mathrm{NH}_{3}-\mathrm{N}(\mathrm{mg} / \mathrm{dL})$ & 12.2 & 11.9 & 11.5 & 11.7 & 0.09 & 0.01 & 0.07 & 0.05 \\
\hline
\end{tabular}

${ }^{1}$ Treatment: 15BRMS, 30BRMS, and 45BRMS indicate the 15\%, 30\%, and 45\% replacement of corn silage with BRMS, respectively.

${ }^{2}$ Probabilities of linear (L), quadratic (Q), and cubic (C) effects. 
Table 7. Effect of replacing corn silage with sugar beet pulp and rice straw mixture silage (BRMS) on the plasma metabolites of dairy cows

\begin{tabular}{|c|c|c|c|c|c|c|c|c|}
\hline Item & Control & \multicolumn{3}{|c|}{ Treatment $^{1}$} & SEM & \multicolumn{3}{|c|}{$P$-value ${ }^{2}$} \\
\hline Glucose $(\mathrm{mg} / \mathrm{dL})$ & 4.85 & 4.90 & 4.93 & 4.89 & 0.02 & 0.42 & 0.28 & 0.78 \\
\hline $\mathrm{BHB}(\mathrm{mg} / \mathrm{dL})$ & 0.75 & 0.65 & 0.50 & 0.48 & 0.05 & 0.02 & 0.80 & 0.82 \\
\hline Plasma urea N (mg/dL) & 5.65 & 5.34 & 5.05 & 5.15 & 0.07 & 0.02 & 0.18 & 0.58 \\
\hline Total protein $(\mathrm{g} / \mathrm{dL})$ & 74.3 & 75.6 & 76.8 & 76.3 & 0.34 & 0.01 & 0.06 & 0.40 \\
\hline
\end{tabular}

${ }^{1}$ Treatment: 15BRMS, 30BRMS, and 45BRMS indicate the 15\%, 30\%, and 45\% replacement of corn silage with BRMS, respectively.

${ }^{2}$ Probabilities of linear (L), quadratic (Q), and cubic (C) effects.

et al., 1991) and an adequate WSC content (>30 g/ kg DM; Zhang et al., 2010a; Guo et al., 2020), which indicated that BRMS meets the silage requirements and has the potential of being used for high quality silage. The WSC content of BRM decreased after silage fermentation, which was mainly due to the substrates (sugar and soluble fiber) utilized by microorganisms to promote the production of lactic acid, since they can rapidly metabolize WSC to lactic acid, leading to an abrupt $\mathrm{pH}$ drop. In this study, the $\mathrm{pH}$ value of BRMS (3.9) was lower than that of CS, and the value of $\mathrm{NH}_{3}-\mathrm{N}$ /total $\mathrm{N}$ (3.15) was lower than that of CS, and Catchpoole and Henzell (1971) reported that the fermentation quality of the silages was good, reflecting a lower terminal $\mathrm{pH}$ and $\mathrm{NH}_{3}-\mathrm{N}$ content, which indicated that the silage quality of BRMS was better than that of $\mathrm{CS}$. The $\mathrm{pH}$ value of BRMS was lower than the result reported by Zhang and Zhang (2011), which may be due to the acceleration of the production of lactic acid due to inoculation. Ogunade et al. (2017) found that a high content of $\mathrm{NH}_{3}-\mathrm{N}$ in silage was a marker of excessive protein breakdown, and the value of $\mathrm{NH}_{3}-\mathrm{N}$ /total $\mathrm{N}$ of BRMS (3.15) in this study was lower than the result reported by Zhang and Zhang (2011), which indicated that the protein breakdown of silage was reduced. The reason might be that the rapid drop of $\mathrm{pH}$ induced by inoculation inhibited the proliferation of harmful microorganisms with hydrolysis and deamination (Muck, 1988; Scherer et al., 2015), effectively preventing the production of $\mathrm{NH}_{3}-\mathrm{N}$. In line with our results, Oliveira et al. (2017) analyzed 130 articles and revealed that the silages treated with one or more bacteria showed a lower $\mathrm{pH}$ and $\mathrm{NH}_{3}-\mathrm{N}$ content compared with those in untreated silages. Few studies have been conducted on BRMS, which limits the comparison of our results with those of other studies.

In this study, the total VFA concentration showed a linear increase with the increasing inclusion of dietary

Table 8. Effects of replacing corn silage with sugar beet pulp and rice straw mixture silage (BRMS) on the DMI, milk yield, milk components, and feed efficiency in dairy cows

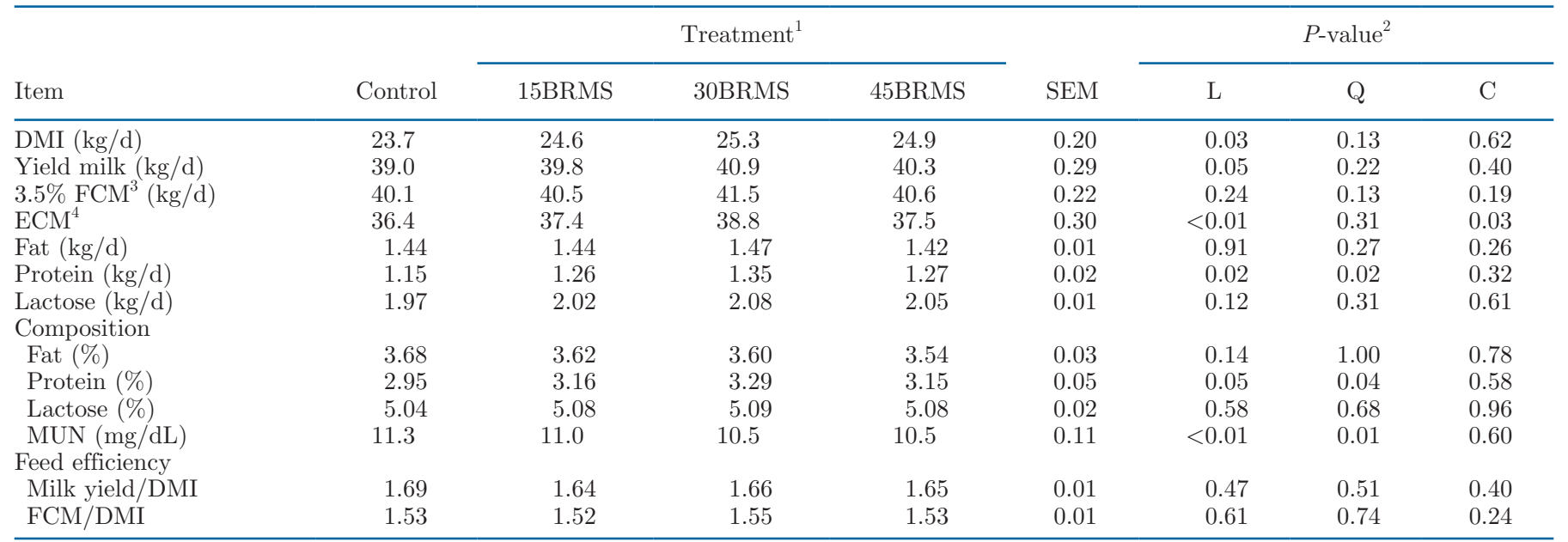

${ }^{1}$ Treatment: 15BRMS, 30BRMS, and 45BRMS indicate the 15\%, 30\%, and 45\% replacement of corn silage with BRMS, respectively.

${ }^{2}$ Probabilities of linear (L), quadratic (Q), and cubic (C) effects.

${ }^{3} \mathrm{FCM}=0.432 \times$ milk yield $+16.23 \times$ fat yield.

${ }^{4} \mathrm{ECM}=$ milk production $\times(0.383 \times \%$ fat $+0.242 \times \%$ protein +0.7832$) / 3.1183(\mathrm{NRC}, 2001)$. 
BRMS. Moreover, Weiss et al. (2009) demonstrated that a high concentration of total VFA was an energy utilization efficiency indicator, which suggested that the inclusion of dietary BRMS increased the energy utilization efficiency. Similar to our results, Heydari et al. (2021) reported that the total VFA in the rumen increased with the increasing inclusion of dietary BP and proposed that the increase in fermentable substrates promoted the proliferation of ruminal microbes. The dietary insufficient energy induced by a low starch content might be compensated for by an increased soluble fiber, sugar, and fiber digestibility, and Silva et al. (1989) demonstrated that the decrease in the total VFA concentration induced by inhibiting the proliferation of rumen microbes was due to the insufficiency of soluble or digestible fiber. Additionally, inoculation was probably another reason for the increase in the total VFA, and Guo et al. (2020) reported that the silage inoculated with LAB had a higher potential of gas production than that did untreated silage.

In this study, the propionate concentration in the rumen had a linear increase with the increasing inclusion of dietary BRMS, which was consistent with the welldocumented effect of a decreasing peNDF content and an increasing NDF digestibility (Maktabi et al., 2016; Naderi et al., 2016). The propionate was the main glucogenic precursor in providing energy for milk synthesis, which indicated that the milk yield might increase with the inclusion of dietary BRMS. In this study, the acetate concentration in the rumen was kept constant with the increasing inclusion of dietary BRMS because acetate concentration was positively correlated with the synthesis of milk fat (Heydari et al., 2021), which is consistent with an unchanged milk fat percentage and production. However, Naderi et al. (2016) found that the acetate concentration decreased with the inclusion of dietary BP, and the differences may be due to BP processing via shredding, which decreased the chewing activity by reducing the dietary peNDF content. In this study, the inclusion of dietary rice straw in the mixture silage compensated for the insufficiency of peNDF, which was consistent with the unchanged peNDF intake. No significant differences were observed in the acetate-to-propionate ratios, which was consistent with the results obtained by Hao et al. (2017).

The ruminal $\mathrm{NH}_{3}-\mathrm{N}$ concentration linearly decreased with the increasing replacement of BRMS in the diets, which might be explained by an increased NDF digestibility to increase the utilization of ammonia by rumen microbes, and MUN data would support that. Inoculation might be another reason for the decrease in the ruminal $\mathrm{NH}_{3}-\mathrm{N}$ concentration, and Guo et al. (2020) reported that corn stover silage inoculated with $\mathrm{LAB}$ had a lower ruminal $\mathrm{NH}_{3}-\mathrm{N}$ concentration than that did untreated silage. The reason for the decreased ruminal $\mathrm{NH}_{3}-\mathrm{N}$ concentration was that the fermentation efficiency (the speed of acidification) was improved by adding $\mathrm{LAB}$ during the initial silage fermentation phase (Muck, 1988; McDonald et al., 1991), which reduced the activity of microbial protease. In this study, the plasma concentration of BHB decreased with the inclusion of dietary BRMS, which was consistent with the results by Naderi et al. (2016). The plasma concentration of UN decreased as the inclusion of dietary BRMS increased up to $45 \%$, which indicated that the energy and protein levels were more balanced with an increasing level of BRMS, since a low UN concentration reflected a high nitrogen efficiency. Wang et al. (2019) demonstrated the increase of TP strengthened tissue protein synthesis and organ growth, and the TP linearly increased as the BRMS increased to up to $45 \%$, which indicated that the dietary inclusion of BRMS enhanced nitrogen efficiency of dairy cows.

In this study, the DMI values of high-producing dairy cows increased with the increasing inclusion of dietary BRMS; similarly, Kargar et al. (2019) reported that the substitution of BP for CS and alfalfa hay had a positive effect on the feed intake, and Heydari et al. (2021) found that a high BP content in the diet caused a linear increase in DMI and NDF digestibility. Kahyani et al. (2019b) found that the WSCS diet (inclusion of BP) contributed to a greater DMI because BP had a high degradable NDF content and a high NDF digestibility, as well as a high cation exchange capacity, and Fustini et al. (2016) demonstrated that a diet with a high degradable NDF content and a high NDF digestibility was the main reasons for an increased DMI. Additionally, the good palatability of BRMS with inoculation was also an important reason (metabolites such as organic acids), and Beiranvand et al. (2019) demonstrated that a high dietary lactic acid content increased the palatability.

The total-tract digestibility of DM, NDF, and ADF increased with the replacement with BRMS by up to $45 \%$. In line with our results, Kahyani et al. (2019b) reported that the DM and NDF digestibility values were improved by the inclusion of dietary BP in highproducing cows, and Heydari et al. (2021) demonstrated that the DM and NDF digestibility values of Holstein dairy cows in mid lactation tended to linearly increase with a higher BP. The NDF digestibility was an important target for improving energy utilization in dairy cows (Reynolds et al., 2011), and an increased NDF digestibility promoted the proliferation of microorganisms and improved the capacity of production of digestive enzymes by microorganisms, thereby further decomposing the nutrients to improve their utilization. Zhang et al. (2010b) found that nutrient digestibility 
was improved by the proliferation of white rumen cocci, yellow rumen cocci, and succinate filamentous fungi.

In this study, the improvement in milk yield was related to the increasing inclusion of dietary BRMS; similarly, Naderi et al. (2016) found that the inclusion of dietary BP improved the milk yield. The improvement in milk yield might be due to high DMI and DM digestibility, which represent a high utilization efficiency of energy and protein. Another possible explanation for the increased milk yield is the change of the ruminal fermentation profile (the increase in propionate concentration). Propionate is the main glucogenic precursor for milk synthesis (Ramanzin et al., 1997). No significant reduction was observed in the milk fat percentage, which was consistent with the constant concentrations of acetate and butyrate. According to the NRC (2001), the ration of a lactating cow should contain at least 200 $\mathrm{g} / \mathrm{kg}$ peNDF, and the peNDF for the replacement diets in this study were more than $200 \mathrm{~g} / \mathrm{kg} \mathrm{DM}$. Therefore, the effective fiber was adequate to keep constant milk fat percentage.

The milk protein production increased with the increasing replacement levels of BRMS in the diets, which was consistent with the results obtained by Naderi et al. (2016), where it was reported that the milk protein production of dairy cows fed an increasing dietary concentration of SBP at the expense of CS linearly increased $(P=0.03)$. The increase in milk protein production may be due to an increased NDICP content with the BRMS replacement increasing in the diets. The increased NDICP content promoted the flow of MP to the small intestine, thereby enhancing the efficiency of nitrogen utilization, which led to a decrease in the ruminal $\mathrm{NH}_{3}-\mathrm{N}$ concentration and to a corresponding decrease in MUN (Naderi et al., 2016). In line with our results, Naderi et al. (2016) reported that the MUN concentration decreased as the replacement levels of dietary BRMS increased, since a low MUN concentration indicated the high efficiency of synthetic bacterial protein (Farmer et al., 2014), which suggested that the protein utilization efficiency increased due to the balance of ruminal energy and protein. In addition, the increase in the dietary $\mathrm{CP}$ intake was also an important reason for the improvement in milk protein production.

The values of feed intake, milk yield, and milk protein production of high-production dairy cows were improved by the partial replacement of CS with BRMS in the diets, and the optimal inclusion ratio of BRMS in place of CS in the diets of high-producing dairy cows was determined to be $45 \%$. The $45 \%$ inclusion in the diet was likely to be a result of a better balance of energy and protein.

\section{CONCLUSIONS}

Feeding diets with the inclusion of BRMS in place of a portion of CS linearly improved the total-tract digestibility and lactation performance of high-production lactating dairy cows, and the effects of replacing levels of up to $45 \%$ were optimal and had no unfavorable effects on the health of the animals. The decreased cost and reduced air pollution associated with BRMS are benefits of its widespread application.

\section{ACKNOWLEDGMENTS}

The authors thank the Agriculture Research System (CARS-36), National Postdoctoral Fund (2016M591504), Postdoctoral Fund in Heilongjiang Province (LBH-Z16032), Basic Scientific Research Program of Department of Education in Heilongjiang Provincial (135409223), Foundation for the Characteristic Discipline of Processing Technology of Plant Foods (YSTSXK201821, 135309113), Development and Reform Support Fund Program from Central Government (2020GSP08), and the Hundreds and Thousands Program (2020ZX06B01). The authors have not stated any conflicts of interest.

\section{REFERENCES}

AOAC. 1990. Official Methods of Analysis, 15th ed. Association of Official Analytical Chemists. https://doi.org/10.1016/0165 -9936(90)87098-7

Beiranvand, H., M. Khani, F. Ahmadi, H. Omidi-Mirzaei, M. Ariana, and A. R. Bayat. 2019. Does adding water to a dry starter diet improve calf performance during winter. Animal 13:959-967. https:/ /doi.org/10.1017/S1751731118002367.

Broderick, G. A., and J. H. Kang. 1980. Automated simultaneous determination of ammonia and total amino-acids in ruminal fluid and in vitro media. J. Dairy Sci. 63:64-75. https://doi.org/10 .3168/jds.S0022-0302(80)82888-8.

Catchpoole, V. R., and E. F. Henzell. 1971. Silage and silage making from tropical herbage species. Herbage 41:213-221. (Abstr.)

Farmer, E. R., H. A. Tucker, H. M. Dann, K. W. Cotanch, C. S. Mooney, A. L. Lock, K. Yagi, and R. J. Grant. 2014. Effect of reducing dietary forage in lower starch diets on performance, ruminal characteristics, and nutrient digestibility in lactating Holstein cows. J. Dairy Sci. 97:5742-5753. https://doi.org/10.3168/jds.2014 $-7963$.

Ferraretto, L. F., A. C. Fonseca, C. J. Sniffen, A. Formigoni, and R. D. Shaver. 2015. Effect of corn silage hybrids differing in starch and neutral detergent fiber digestibility on lactation performance and total-tract nutrient digestibility by dairy cows. J. Dairy Sci. 98:395-405. https://doi.org/10.3168/jds.2014-8232.

Fustini, M., A. J. Heinrichs, A. Palmonari, and A. Formigoni. 2016. Farm characteristics and TMR particle size issues on Parmigiano Reggiano farms in northern Italy. Prof. Anim. Sci. 32:869-873. https://doi.org/10.15232/pas.2016-01550.

Gao, H. J., F. J. Chai, Z. D. Liu, and H. Y. You. 2016. Evaluation quality of alfalfa silage with different water content by applying V-score system. China Feed 12:16-18. https://doi.org/10.15906/j .cnki.cn11-2975/s.20161204.

Guo, C. Q., G. M. Liu, Z. C. Tian, J. H. Zhang, K. X. Chen, and J. H. Huang. 2007. Pathogenicity of Metarhizium (Metsh.) Sorokin and 
Beauveria bassiana on Coptotermes formosanus. J. Hunan Univ. Arts and Sci. 19:34-38.

Guo, G. C. Q., C. Shen, Q. Liu, S. Zhang, T. Shao, C. Wang, Y. Wang, Q. Xu, and W. Huo. 2020. The effect of lactic acid bacteria inoculums on in vitro rumen fermentation, methane production, ruminal cellulolytic bacteria populations and cellulase activities of corn stover silage. J. Integr. Agric. 19:838-847. https://doi.org/10 $.1016 /$ S2095-3119(19)62707-3.

Hao, X. Y., H. Gao, X. Y. Wang, G. N. Zhang, and Y. G. Zhang. 2017. Replacing alfalfa hay with dry corn gluten feed and Chinese wild rye grass: Effects on rumen fermentation, rumen microbial protein synthesis, and lactation performance in lactating dairy cows. J. Dairy Sci. 100:2672-2681. https://doi.org/10.3168/jds.2016-11645.

Heydari, M., G. R. Ghorbani, A. Sadeghi-Sefidmazgi, H. Rafiee, F. Ahamdi, and H. Saeidy. 2021. Beet pulp substituted for corn silage and barley grain in diets fed to dairy cows in the summer months: feed intake, total-tract digestibility and milk production. Animal 15:100063. https://doi.org/10.1016/j.animal.2020.100063.

Jiang, X., H. J. Xu, Z. Q. Cui, and Y. G. Zhang. 2020. Effects of supplementation with Lactobacillus plantarum 299v on the performance, blood metabolites, rumen fermentation and bacterial communities of preweaning calves. Livest. Sci. 239:104120. https:/ /doi.org/10.1016/j.livsci.2020.104120.

Kahyani, A., G. R. Ghorbani, M. Alikhani, E. Ghasemi, A. Sadeghi-Sefidmazgi, K. A. Beauchemin, and S. M. Nasrollahi. 2019b. Performance of dairy cows fed diets with similar proportions of undigested neutral detergent fiber with wheat straw substituted for alfalfa hay, corn silage, or both. J. Dairy Sci. 102:10903-10915. https://doi.org/10.3168/jds.2019-16869.

Kahyani, A., G. R. Ghorbani, M. Alikhani, E. Ghasemi, A. SadeghiSefidmazgi, and S. M. Nasrollahi. 2019a. Adjusting for 30-hour undigested neutral detergent fiber in substitution of wheat straw and beet pulp for alfalfa hay and corn silage in the diet of highproducing cows. J. Dairy Sci. 102:7026-7037. https://doi.org/10 .3168/jds.2018-15740.

Kargar, S., M. Kanani, M. Albenzio, and M. Caroprese. 2019. Substituting corn silage with reconstituted forage or nonforage fiber sources in the starter diets of Holstein calves: Effects on performance, ruminal fermentation, and blood metabolites. J. Anim. Sci. 97:3046-3055. https://doi.org/10.1093/jas/skz180.

Kmicikewycz, A. D., and A. J. Heinrichs. 2015. Effect of corn silage particle size and supplemental hay on rumen $\mathrm{pH}$ and feed preference by dairy cows fed high-starch diets. J. Dairy Sci. 98:373-385. https://doi.org/10.3168/jds.2014-8103.

Lee, C., and A. N. Hristov. 2013. Short communication: Evaluation of acid-insoluble ash and indigestible neutral detergent fiber as totaltract digestibility markers in dairy cows fed corn silage-based diets. J. Dairy Sci. 96:5295-5299. https://doi.org/10.3168/jds.2012 -6442 .

Licitra, G., T. M. Hernandez, and P. J. Van Soest. 1996. Standardization of procedures for nitrogen fractionation of ruminant feeds. Anim. Feed Sci. Technol. 57:347-358. https://doi.org/10.1016/ 0377-8401(95)00837-3.

Maktabi, H., E. Ghasemi, and M. Khorvash. 2016. Effects of substituting grain with forage or nonforage fiber source on growth performance, rumen fermentation, and chewing activity of dairy calves. Anim. Feed Sci. Technol. 221:70-78. https://doi.org/10.1016/j .anifeedsci.2016.08.024.

McDonald, P., A. R. Henderson, and S. J. Heron. 1991. The Biochemistry of Silage. 2nd ed. Cambrian Printers, Ltd.

Miron, J., G. Adin, R. Solomon, M. Nikbachat, A. Zenou, E. Yosef, A. Brosh, A. Shabtay, A. Asher, H. Gacitua, M. Kaim, S. Yaacobi, Y. Portnik, and S. J. Mabjeesh. 2010. Effects of feeding cows in early lactation with soy hulls as partial forage replacement on heat production, retained energy and performance. Anim. Feed Sci. Technol. 155:9-17. https://doi.org/10.1016/j.anifeedsci.2009.09.012.

Mu, L., Z. Xie, L. Hu, G. Chen, and Z. Zhang. 2020. Cellulase interacts with Lactobacillus plantarum to affect chemical composition, bacterial communities, and aerobic stability in mixed silage of high moisture amaranth and rice straw. Bioresour. Technol. 315:123772. https://doi.org/10.1016/j.biortech.2020.123772.
Muck, R. E. 1988. Factors influencing silage quality and their implications for management. J. Dairy Sci. 71:2992-3002. https://doi .org/10.3168/jds.S0022-0302(88)79897-5.

Naderi, N., G. R. Ghorbani, A. Sadeghi-Sefidmazgi, S. M. Nasrollahi, and K. A. Beauchemin. 2016. Shredded beet pulp substituted for corn silage in diets fed to dairy cows under ambient heat stress: Feed intake, total-tract digestibility, plasma metabolites, and milk production. J. Dairy Sci. 99:8847-8857. https://doi.org/10.3168/ jds.2016-11029.

National Research Council (NRC). 2001. Nutrient Requirement of Dairy Cattle. 7th ed. National Academy Press.

Ogunade, I. M., Y. Jiang, D. Kim, A. P. Cervantes, K. Arriola, D. Vyas, Z. Weinberg, K. Jeong, and A. Adesogan. 2017. Fate of Escherichia coli O157: H7 and bacterial diversity in corn silage contaminated with the pathogen and treated with chemical or microbial additives. J. Dairy Sci. 100:1780-1794. https://doi.org/10 $.3168 /$ jds.2016-11745.

Oliveira, A. S., Z. G. Weinberg, I. M. Ogunade, A. A. P. Cervantes, K. G. Arriola, Y. Jiang, D. Kim, X. Li, M. C. M. Gonçalves, D. Vyas, and A. T. Adesogan. 2017. Meta-analysis of effects of inoculation with homofermentative and facultative heterofermentative lactic acid bacteria on silage fermentation, aerobic stability, and the performance of dairy cows. J. Dairy Sci. 100:4587-4603. https://doi .org/10.3168/jds.2016-11815.

Ramanzin, M., L. Bailoni, S. Schiavon, and G. Bittante. 1997. Effect of monensin on milk production and efficiency of dairy cows fed two diets differing in forage to concentrate ratios. J. Dairy Sci. 80:1136-1142. https://doi.org/10.3168/jds.S0022-0302(97)76040 -5 .

Reynolds, C. K., L. A. Crompton, and J. A. N. Mills. 2011. Improving the efficiency of energy utilisation in cattle. Anim. Prod. Sci. 51:6-12. https://doi.org/10.1071/AN10160.

Scherer, R., K. Gerlach, and K. H. Südekum. 2015. Biogenic amines and gamma-amino butyric acid in silage: Formation, occurrence and influence on dry matter intake and ruminant production. Anim. Feed Sci. Technol. 210:1-16. https://doi.org/10.1016/j .anifeedsci.2015.10.001.

Silva, A. T., J. F. D. Greenhalgh, and E. R. Orskov. 1989. Influence of ammonia treatment and supplementation on the intake, digestibility and weight gain of sheep and cattle on barley straw diets. Anim. Prod. 48:99-108. https://doi.org/10.1017/S0003356100003834.

Standardization Administration. National Technical Committee on Feed Industry. 2014. GB/T 30956, 30957, 30955: Determination of Aflatoxin, Deoxynivalenol and Ochratoxin A in feeds: High performance liquid chromatography with immunoaffinity column cleanup[S]. China, Standardization Administration of the PRC.

Standardization Administration. National Technical Committee on Feed Industry. 2012. GB/T 28716-2012: Determination of Ochratoxin A in Feeds: High performance liquid chromatography with immunoaffinity column clean-up[S]. China, Standardization Administration of the PRC.

Sun, S., Y. Jing, F. Wang, Q. Wei, X. Wang, and X. Zhu. 2016. A rapid and sensitive method for determination of trace amounts of glucose by anthrone-sulfuric acid method. Izv. Him. 48:109-113.

Van Soest, P. J., J. B. Robertson, and A. B. Lewis. 1991. Methods for dietary fiber, neutral detergent fiber, and nonstarch polysaccharides in relation to animal nutrition. J. Dairy Sci. 74:3583-3597. https://doi.org/10.3168/jds.S0022-0302(91)78551-2.

Vojvodić, A., D. Komes, I. Vovk, A. Belščak-Cvitanović, and A. Bušić. 2016. Compositional evaluation of selected agro-industrial wastes as valuable sources for the recovery of complex carbohydrates. Food Res. Int. 89:565-573. https://doi.org/10.1016/j.foodres.2016 .07 .023 .

Wang, B., S. Y. Mao, H. J. Yang, Y. M. Wu, J. K. Wang, S. L. Li, Z. M. Shen, and J. X. Liu. 2014. Effects of alfalfa and cereal straw as a forage source on nutrient digestibility and lactation performance in lactating dairy cows. J. Dairy Sci. 97:7706-7715. https://doi .org/10.3168/jds.2014-7961.

Wang, Y., J. Liu, F. H. Wei, X. L. Liu, C. X. Yi, and Y. G. Zhang. 2019. Improvement of the nutritional value, sensory properties and bioavailability of rapeseed meal fermented with mixed microor- 
ganisms. Lebensm. Wiss. Technol. 112:108238. https://doi.org/10 $.1016 /$ j.lwt.2019.06.005.

Weiss, W. P., N. R. St-Pierre, and L. B. Willett. 2009. Varying type of forage, concentration of metabolizable protein, and source of carbohydrate affects nutrient digestibility and production by dairy cows. J. Dairy Sci. 92:5595-5606. https://doi.org/10.3168/jds.2009 -2247 .

Wilson, R. C., T. R. Overton, and J. H. Clark. 1998. Effects of Yucca shidigera extract and soluble protein on performance of cows and concentrations of urea nitrogen in plasma and milk. J. Dairy Sci. 81:1022-1027. https://doi.org/10.3168/jds.S0022-0302(98)75664 -4 .

Yang, W. Z., and K. A. Beauchemin. 2006. Physically effective fiber: Method of determination and effects on chewing, ruminal acidosis, and digestion by dairy cows. J. Dairy Sci. 89:2618-2633. https:// doi.org/10.3168/jds.S0022-0302(06)72339-6.

Zhang, J. G., H. Kawamoto, and Y. M. Cai. 2010a. Relationships between the addition rates of clulose or glucose and silage fermentation at different temperatures. Anim. Sci. J. 81:325-330. https:// doi.org/10.1111/j.1740-0929.2010.00745.x.
Zhang, S. Z., G. B. Penner, M. Abdelqader, and M. Oba. 2010b. Effects of feeding alfalfa hay on chewing, rumen $\mathrm{pH}$, and milk fat concentration of dairy cows fed wheat dried distillers grains with solubles as a partial substitute for barley silage. J. Dairy Sci 93:3243-3252. https://doi.org/10.3168/jds.2009-3011.

Zhang, W. W., and Y. G. Zhang. 2011. Different absorbents affect silage quality and aerobic stability of beet pulp. Chinese J. Anim. Nutr. 23:1577-1583.

Zhao, P., W. X. Wu, J. H. Wu, L. Q. Zhu, H. Xin, X. Yuan, C. H. Yang, K. Yang, and L. H. Sun. 2017. Effects of non-fiber carbohydrate to neutral detergent fiber ratio on rumen fermentation parameters, plasma biochemical indexes and nutrient digestibility of Qianbeima goats. Chinese J. Anim. Nutr. 29:2565-2574. https:/ /doi.org/10.3969/j.issn.1006-267x.2019.11.053.

\section{ORCIDS}

Y. Wang (๑) https://orcid.org/0000-0002-2847-4430

Y. G. Zhang ๑ https://orcid.org/0000-0001-5974-4651 